\title{
Chick Ciliary Ganglion Neurons Contain Transcripts Coding for Acetylcholine Receptor-Associated Protein at Synapses (Rapsyn)
}

\author{
Aime L. Burns, ${ }^{1}$ Deanna Benson, ${ }^{2}$ Marthe J. Howard, ${ }^{3}$ and Joseph F. Margiotta ${ }^{1,3}$ \\ ${ }^{1}$ Department of Physiology and Biophysics and ${ }^{2}$ Fishberg Research Center for Neurobiology, Mount Sinai School of \\ Medicine, New York, New York, and ${ }^{3}$ Department of Anatomy and Neurobiology, Medical College of Ohio, \\ Toledo, Ohio 43699-0008
}

\begin{abstract}
A peripheral membrane protein of $\approx 43 \mathrm{kDa}$ (rapsyn) clusters muscle nicotinic acetylcholine receptors (AChRs), but molecules relevant to clustering neuronal AChRs have not been identified. Here, we have detected rapsyn transcripts in the chick nervous system, localized rapsyn mRNA in ciliary ganglion (CG) neurons, which are known to cluster AChRs, and identified three rapsyn cDNAs derived from the ganglion. Our initial Northern blots, performed using a mouse probe, revealed rapsyn-like transcripts in chick muscle and brain. To develop species-specific probes, we prepared a chick rapsyn cDNA construct, Ch43K.1, that encodes a protein having extensive homology to mouse rapsyn. Using primers designed to anneal near the $5^{\prime}$ and $3^{\prime}$ boundaries of Ch43K.1, three prominent cDNAs were amplified from chick muscle templates by reverse
\end{abstract}

transcriptase based-PCR. Products of similar size were also amplified using cDNA prepared from neuronal tissues expected to contain clustered AChRs (CG and brain), whereas none were detected using templates from tissues not displaying clustered AChRs (sensory ganglia and liver). In situ hybridization confirmed that rapsyn mRNA is expressed both in chick muscle fibers and in CG neurons. Sequencing the three cDNAs amplified from CG templates revealed the largest to be Ch43K.1, whereas the smaller two may represent splice variants. These findings suggest that multiple rapsyn-like molecules are involved in clustering the distinct AChRs expressed by muscle fibers and neurons.

Key words: 43 kDa protein; rapsyn; neuronal AChR; clustering; synapse; mRNA transcripts
Components of chemical synapses are organized in restricted domains (for review, see Jessell and Kandel, 1993). At the neuromuscular junction, nicotinic acetylcholine receptors (AChRs) aggregate in the postsynaptic membrane at $1-2 \times 10^{4} / \mu \mathrm{m}^{2}(\mathrm{Fer}-$ tuck and Salpeter, 1974) directly across from ACh release sites (Heuser and Reese, 1981). Clustered AChRs are crucial for transmission, because ACh applied outside the endplate evokes small, subthreshold depolarizations (Kandel et al., 1991). Rapsyn (AChR-associated protein at synapses) is a $43 \mathrm{kDa}$ peripheral membrane protein believed to be crucial for establishing AChR clusters on mammalian muscle fibers (for review, see Froehner, 1991; Apel and Merlie, 1995). Compelling evidence for this role is that rapsyn and AChRs form clusters when co-expressed in heterologous cells, whereas no clusters are detected when AChRs are expressed without rapsyn (Froehner et al., 1990; Phillips et al., 1991a,b; Brennan et al., 1992; Yu and Hall, 1994). Recent studies also show that muscle from mutant mice carrying a deletion of the Rapsn gene lacks the ability to cluster AChRs (Gautam et al., 1995). Taken together, the findings indicate that rapsyn is sufficient and necessary for clustering muscle AChRs and, because

\footnotetext{
Received Nov. 6, 1996; revised April 21, 1997; accepted April 23, 1997.

This work was supported by National Institutes of Health (NIH) Award NS 24417 and National Science Foundation (NSF) Award IBN-9514560 (J.F.M.), NSF Award IBN-9419900 (D.B.), and NIH Award HD 28184 (M.J.H.). We thank Dr. Stan Froehner (UNC) for providing mouse rapsyn cDNA. We are grateful to Drs. Leslie Henderson, Martin Smith, and Sheridan Swope for helpful discussions, and Drs Robert Duvoisin, Martin Smith, and William Thornhill, and Ms. Desiree Pardi for assistance with molecular approaches.

Correspondence should be addressed to Joseph F. Margiotta, Medical College of Ohio, Department of Anatomy and Neurobiology, 3000 Arlington Avenue, Box 10008, Toledo, Ohio 43699-0008.

The GenBank accession number for the sequence reported in this paper is BankIt 108675 AF000138.
}

Copyright (C) 1997 Society for Neuroscience $0270-6474 / 97 / 175016-11 \$ 05.00 / 0$ rapsyn expressed alone forms aggregates (Phillips et al., 1991b), suggest that it initiates receptor clustering, possibly by first stabilizing AChRs in microclusters.

Although nicotinic synapses are present on neurons (Dennis et al., 1971; Harris et al., 1971; Margiotta and Berg, 1982; Jacob et al., 1984; Wilson Horch and Sargent, 1995), mechanisms relevant to clustering neuronal AChRs have not been elucidated. Given the functional similarity of neuromuscular and neuronal nicotinic synapses and the homology of neuronal and muscle AChRs (for review, see Sargent, 1993), rapsyn-like molecules could participate in clustering neuronal AChRs. We obtained initial support for this hypothesis from Northern blots indicating that rapsyn-like mRNA transcripts are expressed in chick brain. To develop speciesspecific probes for isolating the associated neuronal cDNAs, we cloned and characterized a rapsyn cDNA, Ch43K.1, from a chick muscle library. Ch43K.1 encodes a protein having 91\% homology to rodent rapsyn and displays exon borders similar to those determined previously for the mouse Rapsn gene (Gautam et al., 1994). Interestingly, PCR primer pairs, annealing to the $5^{\prime}$ and $3^{\prime}$ boundaries of Ch43K.1, amplified multiple rapsyn-like cDNAs from chick muscle, brain, and ciliary ganglion (CG) templates. Because CG neurons display two major nicotinic AChR subtypes (containing either $\alpha 7$ subunit or $\alpha 3+\alpha 5+\beta 4$ subunits) (see Vernallis et al., 1993) that cluster both in or near the postsynaptic membrane (Jacob et al., 1984; Wilson Horch and Sargent, 1995), the localization of ganglionic rapsyn transcripts was assessed by in situ hybridization and the PCR products characterized by subcloning and DNA sequencing. The results reveal expression of Ch43K.1 mRNA in CG neurons and heterogeneous ganglionic rapsyn cDNAs, both of which suggest that rapsyn-like molecules may be involved in clustering AChRs on the neurons. 
A preliminary account of our findings has been published previously (Margiotta and Burns, 1995).

\section{MATERIALS AND METHODS}

Northern blots. Total RNA was isolated from embryonic day 16-17 (E16-E17) chicken brain, liver, or pectoral muscle by homogenizing the tissues in $6 \mathrm{~m}$ urea, $3 \mathrm{~m}$ lithium chloride, $0.1 \% \mathrm{SDS}$, followed by phenol/chloroform extraction and ethanol precipitation (modified from Auffray and Rougeon, 1980; Snutch et al., 1990). mRNA was purified by two rounds of poly $\left(\mathrm{A}^{+}\right)$selection using affinity chromatography on oligo(dT)-cellulose (Sambrook et al., 1989), fractionated by electrophoresis on $1.0 \%$ agarose gels containing $6 \%$ formaldehyde, and transferred to Hybond-N nylon filter membranes (Amersham, Arlington Heights, IL). A mouse rapsyn cDNA insert, 1A15, obtained by deleting 5 ' untranslated sequences from M43K.1 to remove an upstream AUG (Froehner, 1989) was excised by digestion with SphI and EcoRI endonucleases and separated on a $1 \%$ agarose gel by electroelution into DEAE-cellulose membrane (NA45, Schleicher and Schuell, Keene, $\mathrm{NH}$ ). Referred to here as M43K.1A, the insert was provided in pBluescript (Stratagene, La Jolla, CA) by Dr. Stanley Froehner (University of North Carolina). ${ }^{32} \mathrm{P}$-labeled M43K.1A cDNA probe was synthesized, with DNA polymerase primed by random hexanucleotides in the presence of $\left[\alpha-{ }^{32} \mathrm{P}\right] \mathrm{dCTP}$, using a labeling kit (Promega, Madison, WI) following the manufacturer's instructions. Filters were incubated in prehybridization solution containing $5 \times$ SSPE, $2.5 \times$ Denhardt's solution, $200 \mu \mathrm{g} / \mathrm{ml}$ salmon sperm DNA, and $1 \%$ SDS at $55^{\circ} \mathrm{C}$ for $4-5 \mathrm{hr}$, and then hybridized overnight at $55^{\circ} \mathrm{C}$ in the same solution containing $10 \%$ dextran sulfate and the ${ }^{32} \mathrm{P}-\mathrm{M} 43 \mathrm{~K} .1 \mathrm{~A}$ probe at $1-3 \times 10^{6} \mathrm{cpm} / \mathrm{ml}$. Nonspecific radioactivity was removed by washing the filters twice for $15 \mathrm{~min}$ each at $55^{\circ} \mathrm{C}$ in $2.0,1.0,0.5$, and $0.2 \times$ SSPE (all concentrations containing $0.1 \%$ SDS). Filters were wrapped in plastic film and exposed to Kodak XAR-5 film (Rochester, NY) for $5 \mathrm{~d}$ at $-80^{\circ} \mathrm{C}$ with a Lightning Plus intensifying screen (DuPont, Billerica, MA).

Library construction and screening. Total RNA was extracted from E16-E17 chick pectoral muscle by homogenization in $4 \mathrm{~m}$ guanididium thiocyanate, followed by phenol/chloroform extraction and ethanol precipitation (Chomczynsky and Sacchi, 1987). The RNA was then treated with $1 \mathrm{U} / \mu \mathrm{l}$ Rnase-free DNase I (Boehringer Mannheim, Indianapolis, IN) and poly $\left(\mathrm{A}^{+}\right)$RNA purified as described above (Sambrook et al., 1989). First-strand cDNAs were synthesized in a $50 \mu \mathrm{l}$ reverse transcription reaction containing $100 \mathrm{ng} / \mu \mathrm{l}$ poly $\left(\mathrm{A}^{+}\right) \mathrm{RNA}, 75 \mathrm{~mm} \mathrm{KCl}, 50 \mathrm{~mm}$ Tris-HCl, $3 \mathrm{~mm} \mathrm{MgCl}_{2}, 1 \mathrm{~mm}$ dNTPs (Pharmacia, Piscataway, NJ), $10 \mathrm{~mm}$ DTT, $1 \mathrm{U} / \mu \mathrm{l}$ RNase inhibitor, $10 \mu \mathrm{M}$ random hexamers (Pharmacia), and $20 \mathrm{U} / \mu \mathrm{l}$ Superscript II reverse transcriptase (RT) (Life Technologies, Gaithersburg, MD) at $37^{\circ} \mathrm{C}$ for $1 \mathrm{hr}$. The second strands were synthesized from the single-strand cDNA templates using Escherichia coli $\lambda$ DNA polymerase I $(500 \mathrm{U} / \mathrm{ml}$, Promega) in the presence of $E$. coli ribonuclease $\mathrm{H}\left(20 \mathrm{U} / \mathrm{ml}\right.$, Promega) for $1 \mathrm{hr}$ at $12^{\circ} \mathrm{C}$ and $1 \mathrm{hr}$ at $21^{\circ} \mathrm{C}$, and the ends blunted with T4 DNA polymerase $\left(40 \mathrm{U} / \mathrm{ml}\right.$, Promega) for $1 \mathrm{hr}$ at $37^{\circ} \mathrm{C}$. After phenol extraction and ethanol precipitation, the blunt-ended double-strand (ds) cDNAs were ligated to EcoRI-NotI linkers $(50 \mu \mathrm{g} / \mathrm{ml}$, Stratagene) using T4 DNA ligase $(30,000 \mathrm{U} / \mathrm{ml}$, New England Biolabs, Beverly, MA) at $16^{\circ} \mathrm{C}$ overnight. Excess linkers and small cDNAs were removed by fractionation over agarose beads (Biogel A-50m, Bio-Rad, Hercules, CA). The linked, ds cDNAs were then ligated into EcoRIpredigested nondephosphorylated bacteriophage $\lambda$ gt10 arms (Stratagene) and packaged into phage heads using Gigapack II Gold packaging extract (Stratagene). The $1.5 \mathrm{ml}$ cDNA library was stored at $4^{\circ} \mathrm{C}$ and its titer determined at $4 \times 10^{6} \mathrm{pfu} / \mathrm{ml}$.

For each screen, bacteriophage was diluted, mixed in top agarose with NM514 $\left(\mathrm{Hfl}^{+}\right)$bacteria, and poured on $150 \mathrm{~mm}$ NZCYM culture plates at $\approx 3 \times 10^{4} \mathrm{pfu} /$ plate. After $6-10 \mathrm{hr}$ at $37^{\circ} \mathrm{C}$, the plates were moved to $4^{\circ} \mathrm{C}$ for 1-12 hr and the plaques transferred in duplicate to Hybond-N nylon filter membranes (Amersham) following the manufacturer's instructions. Filters were incubated in prehybridization solution containing $6 \times$ SSC, $5 \times$ Denhardt's solution, $50 \mu \mathrm{g} / \mathrm{ml}$ denatured salmon sperm DNA, and $0.5 \%$ SDS at $50^{\circ} \mathrm{C}$ for $4-5 \mathrm{hr}$, and then hybridized overnight at $50^{\circ} \mathrm{C}$ in the same solution containing heat-denature ${ }^{32}-\mathrm{P}$-labeled M43K.1A cDNA probe at $1-3 \times 10^{6}$ $\mathrm{cpm} / \mathrm{ml}$. Nonspecific radioactivity was removed by washing the filters twice for $15 \mathrm{~min}$ each at room temperature in $2.0 \times$ SSC containing $0.1 \%$ SDS and twice for $15 \mathrm{~min}$ each in the same wash solution at $55^{\circ} \mathrm{C}$. Filters were exposed to Kodak XAR-5 film for $1-3 \mathrm{~d}$ at $-80^{\circ} \mathrm{C}$ with an intensifying screen. Twelve positive plaques isolated from three primary screening plates of $5 \times 10^{5}$ recombinants were purified by repeated rescreening and phage DNA stocks prepared from each clone. The cDNA clones were then excised from $\lambda \mathrm{gt} 10$ with EcoRI or NotI, separated on 1\% agarose gels, and electroeluted into DEAE-cellulose membranes (Schleicher and Schuell, NA45). A total of seven gel-purified cDNA inserts were then subcloned into the phagemid pBluescript II KS + (Stratagene) and used to transform XL-1 blue bacteria (Stratagene) for dideoxy-DNA sequencing and excision as probes.

$D N A$ sequencing. Sequence information was obtained from both DNA strands by the dideoxynucleotide method using a Sequenase kit, following the manufacturers instructions (USB, Cleveland, OH). Briefly, pBluescript plasmid DNA clones containing inserts to be sequenced were denatured in the presence of universal and/or synthetic oligonucleotides and DMSO, then cooled to allow for annealing. Primers were extended with addition of a dNTP mixture including ${ }^{35}$ S-labeled dATP. Chain growth was terminated by the addition of a dideoxynucleotide triphosphate and the reaction stopped with formamide and EDTA. Samples were denatured and run on a 6\% acrylamide (Acryl-a-Mix 6, Promega) electrophoresis gel. Gels were washed with a 5\% methanol/5\% acetic acid buffer, dried, and exposed to x-ray film overnight at room temperature. Sequence data from the autoradiographs were read using a gel reader interface (CBS, San Diego, CA) and analyzed with the MacVector sequence analysis software package (V5.0, Oxford Molecular).

Reverse transcription-PCR. Total RNA was isolated from E15-E17 chick tissues using the guanididium thiocyanate procedure outlined above (Chomczynsky and Sacchi, 1987). To minimize the possibility of amplifying genomic DNA, RNA (100-500 ng) was treated with $0.1 \mathrm{U} / \mu \mathrm{l}$ Amplification Grade RNase-free DNase (Life Technologies) and then used for cDNA synthesis as described above, except that $10 \mathrm{U} / \mu 1$ reverse transcription was used and the reactions were performed at $40^{\circ} \mathrm{C}$ for $1 \mathrm{hr}$. An identical reaction lacking reverse transcription served as control for possible amplification of genomic DNA. The resulting cDNAs were then used as templates for PCR amplifications in 25-100 $\mu \mathrm{l}$ reactions containing $50 \mathrm{~mm} \mathrm{KCl}, 10 \mathrm{~mm}$ Tris- $\mathrm{HCl}, 2.5 \mathrm{mM} \mathrm{MgCl}_{2}, 400 \mu \mathrm{M}$ dNTPs, $0.1 \mathrm{U} / \mu \mathrm{l}$ Taq DNA polymerase (Boehringer Mannheim), and $0.4 \mu \mathrm{M}$ sense (S1) and antisense (A1) oligonucleotide primers (synthesized by Genset, La Jolla, CA) corresponding to regions of the chick muscle rapsyn (Ch43K.1) near the respective $5^{\prime}$ and $3^{\prime}$ termini (see Fig. $2 B$ ). In some cases, a second round of PCR amplification was performed using cDNAs amplified in the first round as templates and a pair of nested oligonucleotides (S2, A2) as primers. The nested primers were synthesized to include GCTCTAGA (underlined below) at their 5' ends, such that amplification products would contain termini suitable for digestion with $X b a \mathrm{I}$ and subsequent cloning into $X b a \mathrm{I}$-digested pBluescript. The $5^{\prime}$ to $3^{\prime}$ sequences of the primers and their corresponding nucleotide positions (in parentheses) in Ch43K.1 are S1: $\mathrm{A}_{(49)}$ GTGGATTTGGGATTCTAC $_{(67)}$;

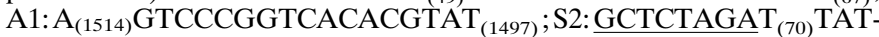
CACCAAACAACCACT $_{(88)}$; and A2: GCTCTAGAG $_{(1399)}$ CAGTTGGTTGTTCTTCTC $_{(1381)}$.

In all cases, PCRs were performed in a thermal cycler (MJ Research, Catham, NJ) using an initial $45 \mathrm{sec}$ melt step at $93^{\circ} \mathrm{C}$, followed by 30 cycles of annealing $\left(50^{\circ} \mathrm{C}, 45 \mathrm{sec}\right)$ and extension $\left(72^{\circ} \mathrm{C}, 60 \mathrm{sec}\right)$, and terminated with an extension at $72^{\circ} \mathrm{C}$ for $4 \mathrm{~min}$. The amplified cDNA products were separated by electrophoresis on $1-2 \%$ agarose gels and visualized by staining with $0.5 \mu \mathrm{g} / \mathrm{ml}$ ethidium bromide.

Southern blots. Southern blots improved the sensitivity for detecting cDNAs beyond that provided by ethidium-stained gels. cDNAs, generated by PCR amplification with S1 and A1 and separated in agarose gels, were transferred to Hybond-N membranes according to the manufacturer's specifications (Amersham) by applying pressure (75 psi) for $1 \mathrm{hr}$ using a pressure-blotting apparatus (PosiBlot 30-30, Stratagene). The DNA was cross-linked to the Hybond filters by UV irradiation (Stratalinker, Stratagene, La Jolla, CA) for $1 \mathrm{~min}$. As probe, a FokI digestion fragment internal to both outer and inner primer pairs (corresponding to nucleotides 876 to 1167) (see Fig. 4A) was isolated from a Ch43K.1 precursor and then subcloned into SmaI-digested pGEM 3Zf (Promega), thereby creating the plasmid pChIN. After excision with HindIII/SacI, pChIN insert was gel-purified and ${ }^{32-}$ P-labeled cDNA probe synthesized in vitro to $1-2 \times 10^{6} \mathrm{cpm} / \mathrm{ml}$ using DNA polymerase primed with random hexanucleotides, as described above. Filters were prehybridized and then hybridized overnight in the same solution containing the ${ }^{32}$-P-labeled ChIN probe. The filters were subsequently washed to high stringency $\left(65^{\circ} \mathrm{C} ; 0.2 \times \mathrm{SSC}\right)$, wrapped in plastic film, and exposed to Kodak XAR-5 film for $0.5-48.0 \mathrm{hr}$ at $-80^{\circ} \mathrm{C}$.

In situ hybridization. Antisense or sense riboprobes were transcribed in the presence of digoxigenin-11-UTP from either EcoRI-linearized pChIN using SP6 RNA polymerase (antisense) or HindIII-linearized plasmid 
using T7 RNA polymerase (sense). Labeling efficiency was assessed using dot blots by comparing the immunological reactivity of synthesized RNA with a serial dilution of digoxigenin-labeled control RNA using antidigoxigenin Fab fragments conjugated to alkaline phosphatase (Boehringer Mannheim). Ciliary ganglia, pectoral muscles, and livers were dissected from E16-E17 chick embryos, fixed in PBS containing 4\% paraformaldehyde for 1-2 hr, cryoprotected in PBS containing 30\% sucrose, and frozen in Tissue-Tek OCT tissue freezing medium (Miles, Elkhart, IN). Cryostat tissue sections were cut at $15 \mu \mathrm{m}$ and thawmounted onto SuperFrost Plus glass slides (Fisher, Pittsburgh, PA), air-dried, and then stored at $-80^{\circ} \mathrm{C}$. In situ hybridization was performed as described by Paradies and Steward (1996). Briefly, frozen sections were thawed, fixed for $10 \mathrm{~min}$ in cold PBS containing 4\% paraformaldehyde, then washed $5 \mathrm{~min}$ in $5 \times$ SSC. Tissue was permeabilized by treatment with $2.6 \mu \mathrm{g}$ of proteinase $\mathrm{K} / \mathrm{ml}$ of $0.1 \mathrm{M}$ Tris, $50 \mathrm{~mm}$ EDTA, $\mathrm{pH} 8.0$, for $30 \mathrm{~min}$ at room temperature, then washed $10 \mathrm{~min}$ in $5 \times$ SSC. Sections were prehybridized in a buffer containing $50 \%$ deionized formamide, $2.2 \times$ SSC, $1.1 \%$ Denhardt's solution, $11 \%$ dextran sulfate, $0.5 \mathrm{mg} / \mathrm{ml}$ tRNA, $0.25 \mathrm{mg} / \mathrm{ml}$ salmon sperm DNA, $0.5 \mathrm{mg} / \mathrm{ml}$ heparin, $5 \mu \mathrm{l} / \mathrm{ml}$ DEP-C treated $\mathrm{H}_{2} \mathrm{O}$ for $1 \mathrm{hr}$ at $42^{\circ} \mathrm{C}$, after which $\sim 5 \mathrm{ng}$ sense or antisense riboprobe in a total volume of $15 \mu \mathrm{l}$ buffer was added to each section and allowed to hybridize at $55^{\circ} \mathrm{C}$ overnight. After hybridization, slides were washed briefly in $2 \times$ SSC, $1 \mathrm{~mm}$ EDTA. Nonspecific binding of probes was removed by incubation in $20 \mu \mathrm{g}$ of RNase $\mathrm{A} / \mathrm{ml}$ of $0.5 \mathrm{M} \mathrm{NaCl}, 10 \mathrm{~mm}$ Tris, $\mathrm{pH} 8.0$, for $30 \mathrm{~min}$ at room temperature. Sections were washed to a final stringency of $0.1 \times \mathrm{SSC}, 1 \mathrm{~mm}$ EDTA at $55^{\circ} \mathrm{C}$ for $2 \mathrm{hr}$. Hybridization was visualized by immunolocalization of the digoxigenin using antidigoxigenin Fab fragments (Boehringer Mannheim) diluted 1:1000 in TBS containing $10 \%$ bovine serum albumin. Alkaline phosphatase was reacted with either 3-Nitro blue tetrazolium salt and 5-bromo-4-chloro3-indoyl phosphate overnight at $4^{\circ} \mathrm{C}$ or a fluorescent substrate, 2-hydroxy3-naphtoic acid-2'phenylanilide phosphate, coupled with Fast Red TR (Boehringer Mannheim) for $60 \mathrm{~min}$ at room temperature.

\section{RESULTS}

\section{Northern blot hybridization analysis}

Initial evidence that rapsyn genes are expressed in the chick nervous system was obtained from Northern blots using a mouse rapsyn cDNA probe (M43K.1A) (Fig. 1). The probe hybridized with chick muscle transcripts of $\sim 2.0,4.0$, and $6.0 \mathrm{~kb}$ (lanes $D, E$ ). In addition to the predominant species at $2.0 \mathrm{~kb}$ (Frail et al., 1988; Froehner, 1989), hybridization with larger transcripts has also been reported for Torpedo electrocytes and Xenopus embryos (Frail et al., 1987; Baldwin et al., 1988). Interestingly, the mouse rapsyn cDNA probe also hybridized with chick brain mRNA transcripts (lanes $B, C$ ). Brain was used as a neuronal RNA source for these experiments, because tissue limitations made it impractical to routinely purify microgram quantities of mRNA from ciliary ganglia (estimated at $2-10 \mathrm{ng} /$ ganglion). The sizes of the hybridizing chick brain transcripts $(\approx 5.8,4.0$, and $2.0 \mathrm{~kb})$ closely paralleled those detected in muscle mRNA, but the signal was generally less intense. The probe showed no detectable hybridization with mRNA obtained from chick liver (lane $A$ ). Because liver mRNA contains neither detectable levels of neuronal AChR protein (Smith et al., 1985; Halvorsen and Berg, 1986) nor subunit mRNA (Boyd et al., 1988), this control indicates appropriate tissue specificity for the hybridization observed with muscle and brain transcripts (lanes $B-E$ ).

\section{Identification of chick muscle rapsyn cDNAs}

To obtain species-specific probes and primers for isolating neuronal rapsyn-like cDNAs, an embryonic chick pectoral muscle cDNA library was prepared and screened with the mouse muscle rapsyn cDNA. A total of $1.5 \times 10^{6}$ recombinants were screened, resulting in the isolation and plaque-purification of twelve clones $\geq 1 \mathrm{kbp}$, seven of which were subcloned in pBluescript and their sequences determined. One clone (8Not 1580) (Fig. $2 A$ ) features a 972 bp open reading frame and displays extensive homology

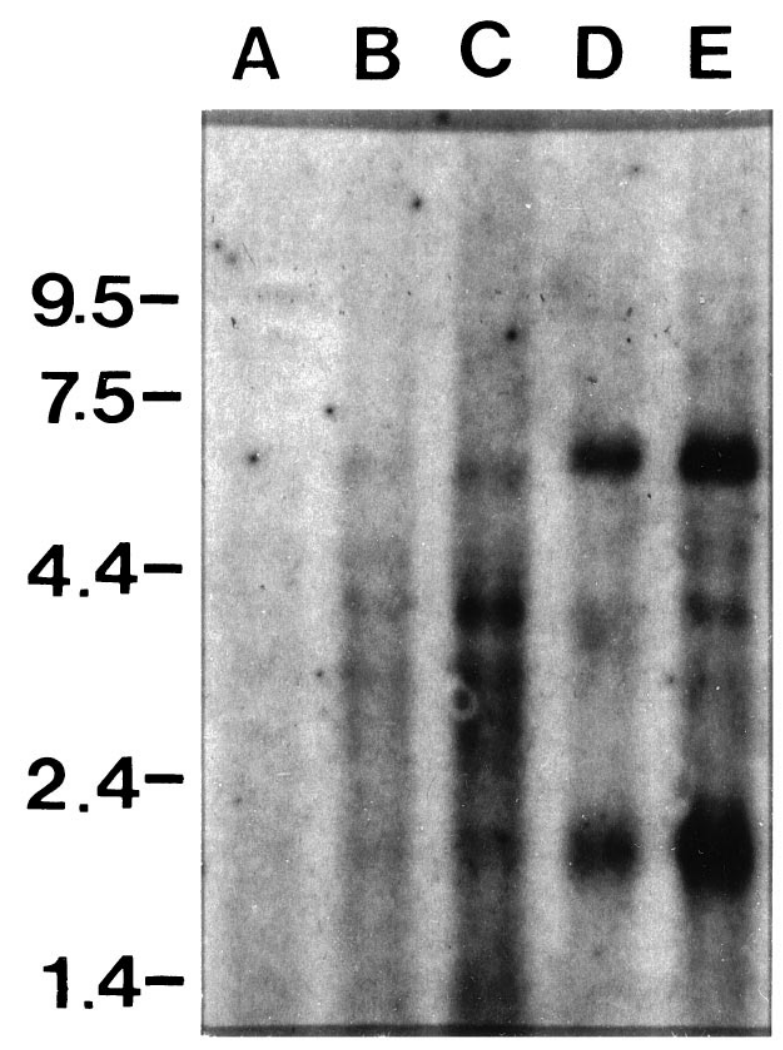

Figure 1. A rodent rapsyn cDNA probe hybridizes with multiple mRNA transcripts in chick muscle and brain. Sources and amounts of chick mRNA transcripts loaded in each lane were liver $(A, 10 \mu \mathrm{g})$, brain $(B, 5$ $\mu \mathrm{g} ; C, 10 \mu \mathrm{g})$; muscle $(D, 5 \mu \mathrm{g} ; E, 10 \mu \mathrm{g})$. Markers to left indicate the size (in kilobases) of RNA standards run on the original agarose gel.

with the $5^{\prime}$ two thirds of M43K.1A (data not shown), including the position of the putative translation start ATG (see below). A second clone, also generated by NotI digestion (5.1Not 1750) (Fig. $2 \mathrm{~A})$, contains a $1050 \mathrm{bp}$ reading frame that overlaps in sequence with 8 Not 1580 over a 783 bp region and features an in-frame stop TGA. The nonoverlapping regions of the clones (dashed lines) coincide with interruptions by possible introns, as described for the mouse Rapsn gene (Gautam et al., 1994). Because the total RNA used to create the library was treated with DNase I before poly $\left(\mathrm{A}^{+}\right)$selection (see Materials and Methods), we assume that both 5.1 Not 1750 and 8 Not 1580 arose from reverse transcription of hnRNA transcripts, and not from contaminating genomic DNA. The cDNA inserts were digested at a common BspHI restriction site and the appropriate size fragments isolated and ligated (Fig. 2A) and subcloned into NotI-digested pBluescript, creating the plasmid pCh43K.1.

Sequencing the $1548 \mathrm{bp}$ pCh43K.1 insert revealed a continuous 1236 bp open reading frame bounded by translation initiation and termination codons starting at positions 268 and 1504, respectively (Fig. 2B). Although an in-frame ATG is also found at position 244, the ATG starting at position 268 is more likely to represent the true translation initiation codon. First, a purine $(\mathrm{G})$ is three positions upstream from $\mathrm{A}_{268}$, thereby providing a more appropriate context for translation initiation than the pyrimidine $(\mathrm{T})$ three positions upstream from $\mathrm{A}_{244}$ (Kozak, 1986). Second, comparison of Ch43K.1 with cDNAs from mouse BC3H1 cells (Frail et al., 1988; Froehner, 1989), Xenopus (Baldwin et al., 1988), and Torpedo (43k.7) (Frail et al., 1987) reveals an abrupt loss of 
A

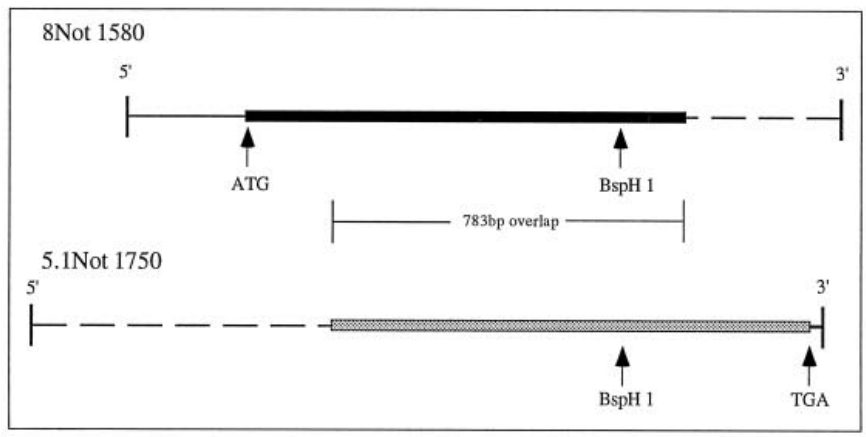

Ch43K.1

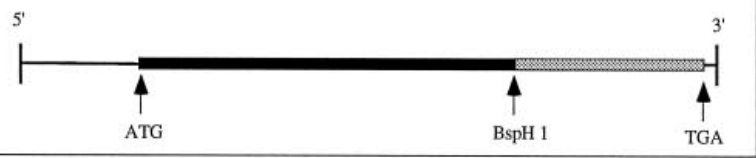

B

61

121

181

241

301

12

361
32

421
52

481

541

92

112

661

132

721
152

78

172

841

102

212

961

232

1021
252

1081

272

1141

292

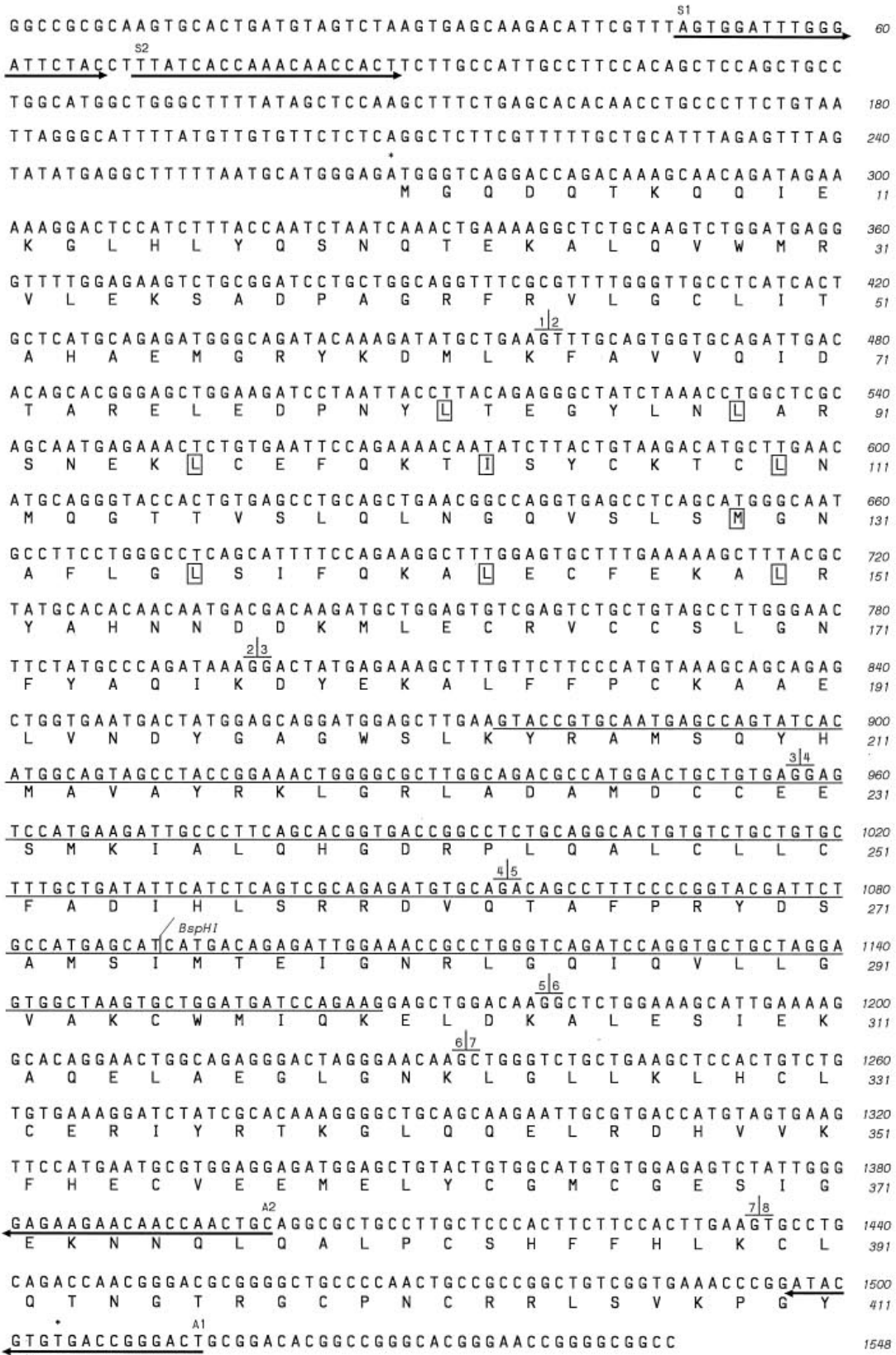

Figure 2. Isolation and characterization of chicken muscle rapsyn cDNAs. $A$, Two $\lambda$ gt10 clones isolated by screening a chick muscle library with mouse rapsyn cDNA are depicted. One (8Not 1580) featured a 972 bp open reading frame (black bar) displaying high homology with the $5^{\prime}$ two thirds of M43K.1A, including the position of the putative start ATG at A268 (arrow). A second clone (5.1Not 1750) contained a $1050 \mathrm{bp}$ open reading frame (gray bar) that overlapped in sequence with 8 Not 1580 over a 783 bp region and featured an in-frame stop TGA. The cDNA inserts were digested at a shared $B s p \mathrm{HI}$ restriction site and the fragments ligated and subcloned into linearized pBluescript to form the plasmid pCh43K.1. B, Nucleotide sequence of chicken muscle cDNA construct Ch43K.1 (top line) and the predicted amino acid sequence of the protein in one letter code (bottom line) are shown. The $1236 \mathrm{bp}$ open reading frame of the cDNA is bounded by a start ATG codon at position 268 and a stop TGA codon at position 1504. Regions of Ch43K.1 corresponding to exon borders in the mouse Rapsn gene (Gautam et al., 1994) are shown as inverted Ts separating the appropriate exon numbers. Leucine as well as isoleucine and methionine residues (leucine alternatives) (see Landschulz et al., 1988; Froehner, 1991) within the leucine zipper motif of exon 2 are depicted in boxes. The underlined region (from nucleotides 876 to 1167) represents a cDNA fragment (ChIN) used to prepare probe for detecting PCR products on Southern blots (see Materials and Methods; Fig. 4). Bold arrow segments near the $5^{\prime}$ and $3^{\prime}$ borders indicate regions corresponding to distal (S1 and $\mathrm{A} 1)$ and nested (S2 and A2) sense-antisense synthetic oligonucleotide primer pairs used in PCR experiments (see Materials and Methods; Results). 
FA

\begin{tabular}{|c|c|c|}
\hline Chick & & 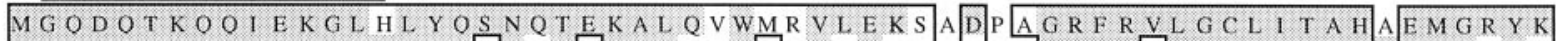 \\
\hline Torpedo & & M G O D O T K O O I E K G L OL Y OAN E T GK A L E I WQQ V V E R S T E L P G R F R A L G C L I T A HS E M G K Y E \\
\hline Xenopus & & 1 G ODOTKOOOI OK GL OMYOS NOT E K A L O I W T K V L E K T T D A A G R F R V L G C L I T A H S E M G R Y K \\
\hline ouse & & 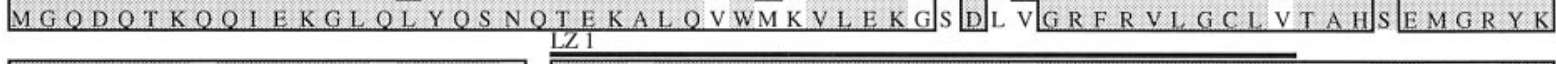 \\
\hline Chick & & MLKFAVVOIDTARELEDPNY LTEGYLNLARS NEKLCEFQKTISYCKTCLNMQGTT \\
\hline edo & & 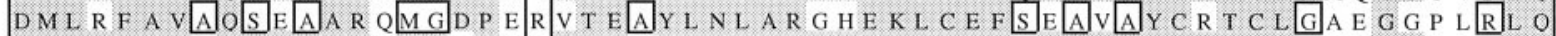 \\
\hline pus & & 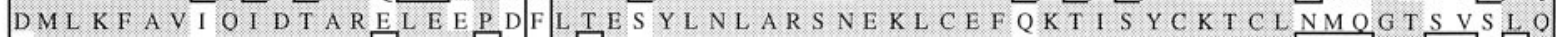 \\
\hline se & & 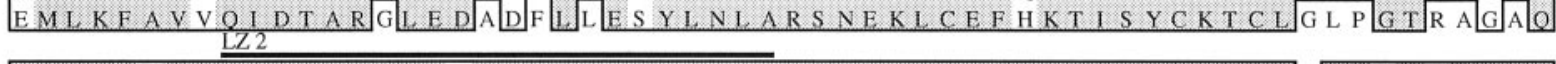 \\
\hline Chi & & L N G OVSLSMGNAFL GL S I F O K A L E CFEKALR Y A H N D I \\
\hline Torpedo & & F N GOV C L S M G N A F L G L SAF OKA L E C F E K A L R Y A HGN D D K M L E C R V C C S L GAF Y V O L K D Y E \\
\hline opus & & L N G O VLC S L G N A Y G L S V F O K A L E C F E K A L R Y A H N N D D K M L E C R V C C S L G GL Y T O L K DLL \\
\hline Mou & & LGGOVSLSMGNAFLGLSLFOKALESTEKALRYAHNNDDTMLECR VCCSLGSLYAOVKDYE \\
\hline Chi & & L F F P C KA A E L V N D Y G A G \\
\hline Torpedo & & K A L F F P C K S A E L VAD Y GR G W S L K Y K A M S R Y H M A A A Y R K L G R M DD A M \\
\hline opus & & K A L F F P C K A A E L V N D Y G K G WS L K YRAMS OYHMA VA YRKLGRAADAM I \\
\hline Mouse & & 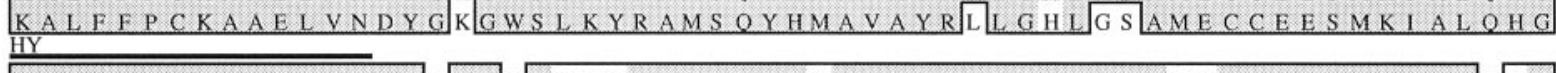 \\
\hline Chick & & C L L C F A D I H L S R R D Q TAF P R Y D S AMS I M T E I C \\
\hline edo & & D R P L O A L C L L C F A D I HR H R S D I G K A L P R Y E S S L N I M T E I G N R L G OA H V L L N I A K C I \\
\hline opus & & D R P L OAL C L L NF A D I H R S H G D I E K A F P R Y D S S S S I M T D I G N R L G OTH V M I G V A K C \\
\hline touse & & DRPLOALCLLCFADIHRSR GDLETAFPRYDSAMSIMTEIG \\
\hline Chick & & E L D KALE I E K A Q L A E L G KLGLLKLHCLCER I YRTKGLQ QELR D \\
\hline Torpedo & & 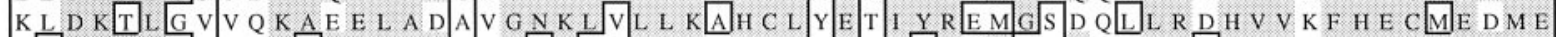 \\
\hline Хепори: & & E M D K A L D C L Q K T O E L A E D I G Y K H C L L K V H C L S E I I E R T K O O O R E L R A H V V R F H E C V E E M E \\
\hline Mouse & 301 & $\underset{\mathrm{ZF}}{\mathrm{Z}} \mathrm{Q} D \mathrm{D}$ K A L D A I E K A O D L A E E V G N K L S Q L KL H C L S E S I Y R S K GL OR D V R T H V VRF H E C \\
\hline & & $\mathrm{R} R \mathrm{~L}$ \\
\hline Torpedo & 36 & C P N C K R S S V K P G Y V \\
\hline enopus & 3 & L Y C GMC GE S I G E K N C Q L OA L P C S H V F H L R C L OT N G T R G CL \\
\hline Mouse & 361 & 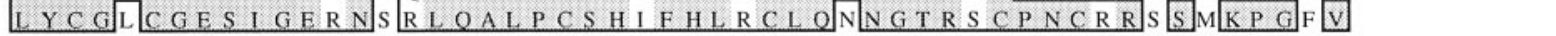 \\
\hline
\end{tabular}

Figure 3. Homology of the predicted chick rapsyn protein with those from Torpedo, Xenopus, and mouse. Individual amino acid residues were aligned without insertions or gaps, beginning at the start methionine. Identical and similar residues are included within the large box borders; identical residues are shaded. Domains corresponding to fatty acid myristoylation $(F A)$, leucine zipper $(L Z 1, L Z 2)$, and zinc finger $(Z F)$ motifs of mouse rapsyn, as well as a conserved hydrophobic middle region $(H Y)$, are indicated by the dark bars.

otherwise extensive homology $5^{\prime}$ to $\mathrm{A}_{268}$ in all three cases (data not shown), suggesting that these regions of the clones represent 5 ' untranslated sequences. Because the open reading frames of chick and mouse rapsyn cDNAs are highly homologous and regions corresponding to exon borders in mouse (Gautam et al., 1994) are preserved in chick, the borders of eight exons can be tentatively assigned for Ch43K.1 (Fig. 2B). The tentative exon identification is useful here, because partial and complete deletions of exon 2 are detected in neuronal Ch43K.1 variants (see below) and may have functional relevance. The $3^{\prime}$ end of Ch43K.1 features an in-frame translation termination TGA starting at nucleotide 1504 but lacks a poly(A) tail in the subsequent $3^{\prime}$ untranslated region (1507-1549). The absence of a poly(A) tail is not surprising, however, because the cDNA library from which the clones were generated was primed with random hexamers rather than with oligo dT primers (see Materials and Methods).

\section{Characterization of chick muscle rapsyn}

Ch43K.1 is predicted to encode a $46.8 \mathrm{kDa}$ rapsyn protein composed of 412 amino acids. Alignment of the chick sequence with those of proteins encoded by Torpedo 43k.7 (Carr et al., 1987; Frail et al., 1987) and mouse (Frail et al., 1988; Froehner, 1989) cDNAs and with that of a partial sequence obtained from Xenopus (Baldwin et al., 1988) revealed extensive interspecies homology (Fig. 3) (see below). The overall percent identity/homology of chick muscle rapsyn with mouse (412 amino acids, $46.4 \mathrm{kDa}$ ) and Torpedo (412 amino acids, $46.5 \mathrm{kDa}$ ) rapsyns is $86 / 91$ and $79 / 87 \%$, respectively, and with the Xenopus rapsyn peptide (399 amino acids, $45.5 \mathrm{kDa}$ ) is $89 / 94 \%$.

Chick muscle rapsyn displays the same structural motifs thought to represent functional domains in mouse (Froehner, 1991), where they have been correlated with individual exons (Gautam et al., 1994). Of the 64 amino acids encoded by mouse exon 1 , the $\mathrm{N}$-terminal 15 residues are highly conserved with only two nonidentities among chick, mouse, Xenopus, and Torpedo rapsyn proteins. In all four species, this conserved motif (Fig. 3, $F A$ ) includes a glycine at position $2(G 2)$ and small uncharged residues at positions Q3 and T6, an appropriate context for recognition by $N$-myristoyl-transferase (Froehner, 1991; Gautam et al., 1994). For mouse rapsyn, preventing N-terminal myristoylation by converting $\mathrm{G} 2$ to A reduced the formation of plasma membrane rapsyn aggregates, suggesting that $\mathrm{N}$-terminal addition of myristic acid is necessary for efficient intercalation into the lipid bilayer (Phillips et al., 1991b). Within the boundaries encoded by mouse exon 2 (residues 65-177), two putative leucine heptad repeat motifs (L82-L110 and M129-L150) forming eight and six $\alpha$-helical turns, respectively, have been identified (Froehner, 1991; Phillips et al., 1991b; Gautam et al., 1994). These "leucine zippers" (Landschulz et al., 1988) are highly conserved among chick, mouse, Xenopus, and Torpedo rapsyn proteins (Fig. 3, LZ1, LZ2), and coincide with two of the eight tetratrico peptide repeats (TPR3 and TPR4) recently proposed for rapsyn proteins (Ponting and Phillips, 1996). Both structures are $\alpha$-helical, and LZs have been speculated to permit rapsyn homodimerization or het- 


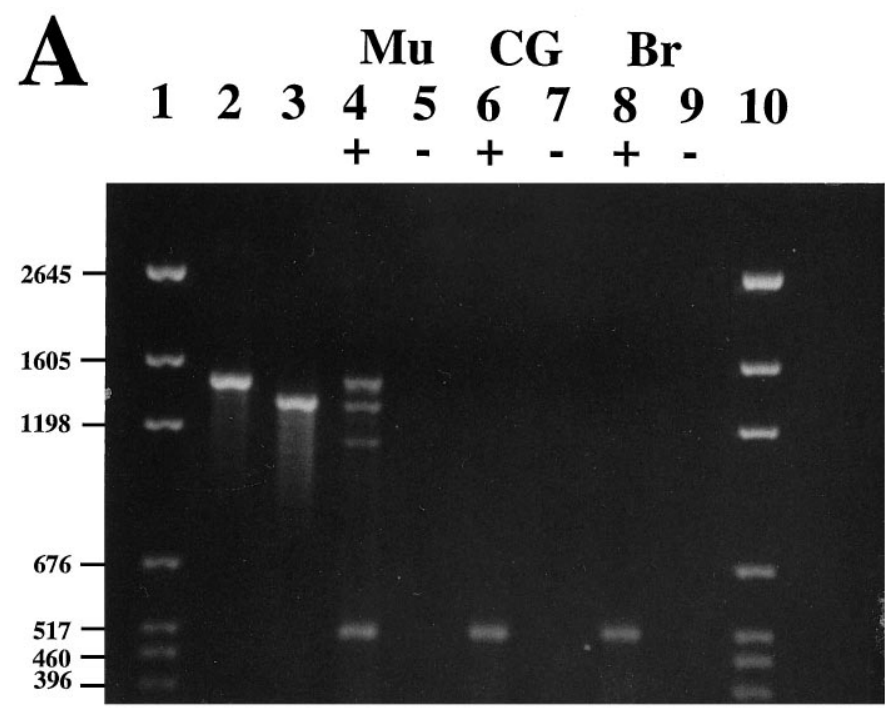

B Mu CG Br DRG Lv

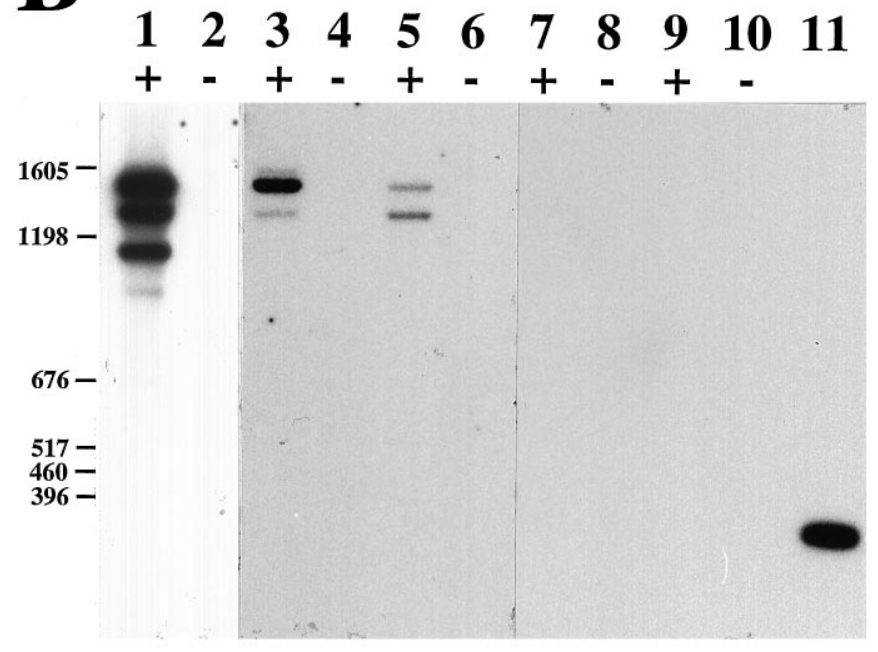

Figure 4. Amplification of rapsyn-like cDNAs from chick muscle and neuronal tissue templates. $A$, PCR products detected with ethidium bromide staining. Control template reactions (lanes 2,3) revealed single products of $\approx 1470$ or $1350 \mathrm{bp}$ after amplification of Ch43K.1 insert using primer pairs S1/A1 or S2/A2, respectively. Subsequent test reactions (lanes 4-9) using only the S1/A1 primer pair reveal products amplified from muscle $(M u)$, ciliary ganglion $(C G)$, or brain $(B r)$ cDNA templates, synthesized by reverse transcription of cellular RNA (+; lanes 4, 6, 8). Note that multiple products are amplified from muscle cDNA templates $(\sim 1500,1350,1150$, and $500 \mathrm{bp}$; lane 4$)$, whereas only a $500 \mathrm{bp}$ product is amplified from brain and ganglionic templates (lanes 6, 8). Negative controls, using "sham" reverse transcriptions from corresponding muscle, brain, and CG reactions lacking RT (-; lanes 5, 7, 9), revealed no products. pGEM DNA marker was loaded in lanes 1 and 10 , and sizes are labeled at left. $B$, Tissue PCR products amplified as in $A$ were detected by Southern blot hybridization using the ${ }^{32}$-P-labeled ChIN probe (see Materials and Methods; Fig. 2B). Autoradiograms exposed for $1 \mathrm{hr}$ from reactions using muscle templates (lane 1) detected the three cDNA products $(\sim 1500,1350,1150)$ resolved on ethidium-stained gels (compare with $A$ ) as well as a less intense product at $1000 \mathrm{bp}$. Subsequent lanes $(3-10)$ depict PCR products amplified from $\mathrm{CG}, \mathrm{Br}, D R G$, and liver $(L v)$ templates exposed for 10-24 hr. Note that the same two product sizes seen for $\mathrm{Mu}$ reactions $(\sim 1500$ and $1350 \mathrm{bp})$ are also resolved in $\mathrm{CG}$ and $\mathrm{Br}$ reactions (lanes 3,5$)$ and that an additional product of $1600 \mathrm{bp}$ is detected in CG. No products are detected in amplifications from DRG (lane 7) or erodimerization with other membrane-associated proteins by coiled coil interactions (Phillips et al., 1991b). In the region corresponding to that encoded by mouse exon 3 (residues $178-$ 230) five tyrosine residues are conserved in chick rapsyn (Fig. 3, asterisks) and could serve as substrates for tyrosine kinase phosphorylation accompanying AChR clustering (Hall and Sanes, 1993). The entire mouse exon 4 encodes a region (residues 231263) that is particularly well conserved among chick, mouse, Xenopus, and Torpedo ( $\approx 88 \%$ identity) and includes a hydrophobic domain (Fig. 3, $H Y$ ) speculated previously to form nonionic interactions with AChR subunits independent of any leucine zipper interactions (Phillips et al., 1991b). Consistent with the functional importance of rapsyn's central region, a truncated mouse protein lacking the leucine zipper and hydrophobic domains (residues 16-254) failed to cluster AChRs but formed normal rapsyn aggregates (Phillips et al., 1991b). Finally, mouse exons 7 and 8 encode two tandem zinc-binding motifs (residues 363-402) conserved among chick, mouse, Xenopus, and Torpedo rapsyns (Fig. 3, $Z F$ ) that fit the $\mathrm{CCCH}-\mathrm{HCCC}$ two-finger sequence (Froehner, 1991). These "zinc-finger" motifs have been implicated in mediating rapsyn homoaggregation, because mutations in the region greatly reduce rapsyn clustering (Scotland et al., 1993).

\section{Detection of multiple rapsyn transcripts in muscle and neuronal tissues}

Synthetic oligonucleotide primer pairs derived from Ch43K.1 cDNA (Fig. 2B) were used to amplify rapsyn-like cDNAs from chick muscle and neuronal templates obtained by reverse transcription of total cellular RNA (Fig. 4). Using the outer (S1 and A1) or inner (S2 and A2) PCR primer pairs in separate amplifications of Ch43K.1 template revealed single ethidium-stained products on agarose gels (Fig. 4A, lanes 2,3) having the expected sizes of $\sim 1470$ or $1350 \mathrm{bp}$. When amplifications were performed using the S1 and A1 primer pair on chick muscle cDNA templates, three products of $\sim 1350,1150$, and $500 \mathrm{bp}$ were detected in addition to the expected product of $\sim 1500$ bp (Fig. $4 A$, lane 4 ). The muscle products were judged to represent amplified cDNA rather than genomic DNA templates, because RNA was always pretreated with DNase, and because no products were detected in amplifications where reverse transcription was omitted from the initial reverse transcription reaction (e.g., Fig. 4A, lanes 5, 7, 9). In addition, the products do not arise from a general cellular transcript, because control experiments using the same S1 and A1 primer pair revealed no ethidium-stained products using cDNA templates generated from liver or dorsal root ganglion (DRG) (see below). The latter control is noteworthy, because whereas chick DRG neurons express functional nicotinic AChRs (Margiotta and Howard, 1994) and AChR $\alpha$-subunit mRNA (Boyd et al., 1991), they are not known to receive synaptic inputs and do not form aggregates of mAb35 immunoreactivity that would be indicative of clustered AChRs (J. Margiotta, unpublished observations). The RT-PCR detection of several muscle-derived rapsyn cDNAs, in addition to the expected $1500 \mathrm{bp}$ product, suggests that multiple rapsyn transcripts are expressed in chick muscle.

Lv (lane 9) templates, even after exposures $>36 \mathrm{hr}$. As in $A,+$ (lanes 1, 3, $5,7,9)$ and - (lanes $2,4,6,8,10)$ denote presence or absence, respectively, of RT from the initial reverse transcription reaction. Lane 11 depicts the migration of the 292 bp ${ }^{32-}$ - - labeled ChIN probe. Size markers are pGEM standards (in base pairs) reproduced from the original agarose gel (data not shown). 
When the S1 and A1 primer pair was used to amplify cDNA templates generated by reverse transcription of chick brain or CG RNA, only the 500 bp PCR product was detected on ethidiumstained agarose gels (Fig. $4 A$, lanes 6,8 ). Because Northern blots suggested that rapsyn-like mRNA transcripts are expressed at low abundance in chick brain (Fig. 1), the sensitivity of the RT-PCR assay was increased to detect products generated by templatelimited amplifications. This was accomplished by transferring the gel-fractionated products to nylon filter membranes and probing the filters at high stringency with ${ }^{32-} \mathrm{P}$-labeled pChIN insert DNA corresponding to nucleotides $876-1167$ of Ch43K.1 (Fig. 4B). In control amplifications of muscle cDNA, the resulting autoradiograms exposed for $\approx 1 \mathrm{hr}$ revealed three major products at 1500 , 1350, and $1150 \mathrm{bp}$ indistinguishable in size from those detected on ethidium-stained gels, as well as a faint product at $\approx 1000 \mathrm{bp}$ (compare Fig. $4 B$, lane 1 with $4 A$, lane 4 ). After exposures $>2 \mathrm{hr}$, an additional product of $\approx 700$ bp was also apparent (data not shown). The ability to detect the 1000 and 700 bp products probably reflects the higher sensitivity of this assay over ethidium staining. Alternatively, the $500 \mathrm{bp}$ product apparent on agarose gels after amplifications of muscle, CG, or brain templates was not detected on the Southern blots even after exposures $>10 \mathrm{hr}$. We interpret this finding to mean that the $500 \mathrm{bp}$ product lacks sufficient sequences complementary to the ChIN probe used for the Southern blots. Using the Southern approach, brain and CG autoradiograms exposed for $\geq 10 \mathrm{hr}$ (Fig. 4B, lanes 3,5) revealed products at 1500 and $1350 \mathrm{bp}$ that were indistinguishable in size from the two largest products detected from identical amplifications using muscle templates. Interestingly, a third product ( $\approx 1600 \mathrm{bp}$ ), larger than expected for amplification of Ch43K.1 cDNA using S1 and A1, was also detected in amplifications from $\mathrm{CG}$ templates. The $\mathrm{CG}$ and brain products do not represent amplification of genomic DNA, because they were undetected in reactions lacking cDNA (lanes 4, 6), nor do they represent a transcript common to all cells, because they were not seen, even after long exposures ( $\geq 72 \mathrm{hr}$ ) in test reactions from DRG or liver (lanes 7,9). These results support the idea that multiple rapsynlike cDNAs (corresponding to products at 1500, 1350, and $500 \mathrm{bp}$ ) are expressed as mRNA in chick muscle, brain, and CG. They suggest further that a $1600 \mathrm{bp}$ product may represent a rapsyn-like cDNA unique to the $\mathrm{CG}$.

\section{Cellular localization of rapsyn transcripts}

Rapsyn transcript was localized in tissue sections from chick pectoral muscle and ciliary ganglia by nonradioactive in situ hybridization histochemistry (Fig. 5) using riboprobes transcribed from linearized pChIN. Hybridization visualized using either fluorescent or nonfluorescent substrates for alkaline phosphatase gave similar results in three separate experiments. In chick pectoral muscle sections, hybridization with antisense riboprobe revealed intense labeling of striated muscle fibers and muscle spindles, whereas intervening connective tissue was unlabeled (Fig. $5 A, B)$. Muscle sections hybridized with sense (control) riboprobe displayed no labeling above background levels $(C)$. In CG sections, the antisense riboprobe hybridized with mRNA transcript contained within a subpopulation of cells $(D)$ identified previously as neuronal by their large size, round shape, and basophilic staining (Thomas et al., 1993). When sections were examined using bright-field differential interference contrast optics, most of the label was seen to be contained within neuronal cell bodies (e.g., compare arrows in $D$ and $E$ ). Hybridizing ganglion sections with sense (control) riboprobe revealed no detectable specific labeling $(F)$. In two separate experiments, liver sections hybridized with antisense pChIN probe displayed no labeling above background levels (data not shown). These findings confirm the expression of Ch43K.1 mRNA within chick muscle fibers and CG neurons and demonstrate that at least some fraction of the transcripts amplified by RT-PCR (Fig. 4B) are expressed by the neurons in situ.

\section{Identification of neuronal rapsyn-like cDNAs}

Because CG neurons express two major AChR subtypes (Vernallis et al., 1993) and both subtypes form postsynaptic clusters (Jacob et al., 1984; Wilson Horch and Sargent, 1995), we next focused on characterizing rapsyn-like cDNAs derived from the ganglion. To obtain quantities of cDNA sufficient for isolation and subcloning, secondary amplifications were performed using a nested primer pair (S2 and A2) (Figs. 2B, 6). Ganglionic cDNA templates for these amplifications were obtained from aliquots of PCR reactions primed by the outer pair (S1 and A1) or by separating products from such reactions on low-melting-point agarose gels and excising regions expected to contain material of 800-1600 bp. Using either approach, three discrete products of $\approx 1350,1250$, and 1000 bp were detected on ethidium-stained agarose gels (Fig. 6A). Assuming homology with Ch43K.1, the templates for these secondary amplifications would be $120 \mathrm{bp}$ larger than the products (i.e., 1470, 1370, and $1120 \mathrm{bp}$, respectively), given the locations of inner and outer primer annealing sites (Fig. 2B). It is interesting to note that these presumed template sizes are indistinguishable from the three major PCR products detected from primary amplifications of muscle cDNAs and correspond to two of the brain and ganglionic primary PCR products of 1500 and $1350 \mathrm{kbp}$ detected on Southern blots (Fig. 4). The $1120 \mathrm{bp}$ template inferred from secondary amplifications of ganglionic cDNA correlates well with the 1150 bp product obtained in primary amplifications of muscle cDNA. A correlate of the $1600 \mathrm{bp}$ ganglionic fragment amplified using the outer primers and detected on Southern blots has not yet been identified in secondary amplifications using the nested primer pair (compare Figs. 4 and $6 A$ ). This finding would be explained if the $1600 \mathrm{bp}$ ganglionic product differed from Ch43K.1 by the inclusion of a unique region, 5', to that recognized by A1 and replacement of the site recognized by A2.

To determine the relationship of the ganglionic cDNAs to Ch43K.1, the products from secondary amplifications were isolated by gel purification and subcloned (Fig. $6 A$ ) for sequencing. Thus far, complete sequence information has been obtained for three CG plasmid clones (CG7, 11, and 4) (Fig. 6B), and an additional five clones have been partially characterized (CGB, 8, 9,12 , and 3). Clone pCG7 contains a 1330 bp insert, CG7, which is identical to Ch43K.1 over the region bounded by primers $\mathrm{S} 2$ and A2 (nucleotides 70-1399). Clone pCG11 contains an 1183 bp insert identical to CG7 except for an in-frame $147 \mathrm{bp}$ deletion corresponding to Ch43K.1 nucleotides 460-606 (Fig. 6B). Partial sequence information and PCR detection indicate that clones pCGB, 8, and 9 are identical to pCG11 (data not shown). Similar results indicate that clone pCG12 is similar to CG11, but not identical in the deleted region. CG4 contains a 991 bp insert, identical to Ch43K.1 except that it displays a more extensive in-frame 339 bp deletion than CG11, which corresponds exactly to the nucleotides comprising proposed exon 2 (460-798). Clone pCG3 appears identical to pCG4. The insert sizes of the ganglionic clones correspond well to the 1350, 1250, and 1000 bp cDNA products amplified from ganglionic templates with primers S2 and 


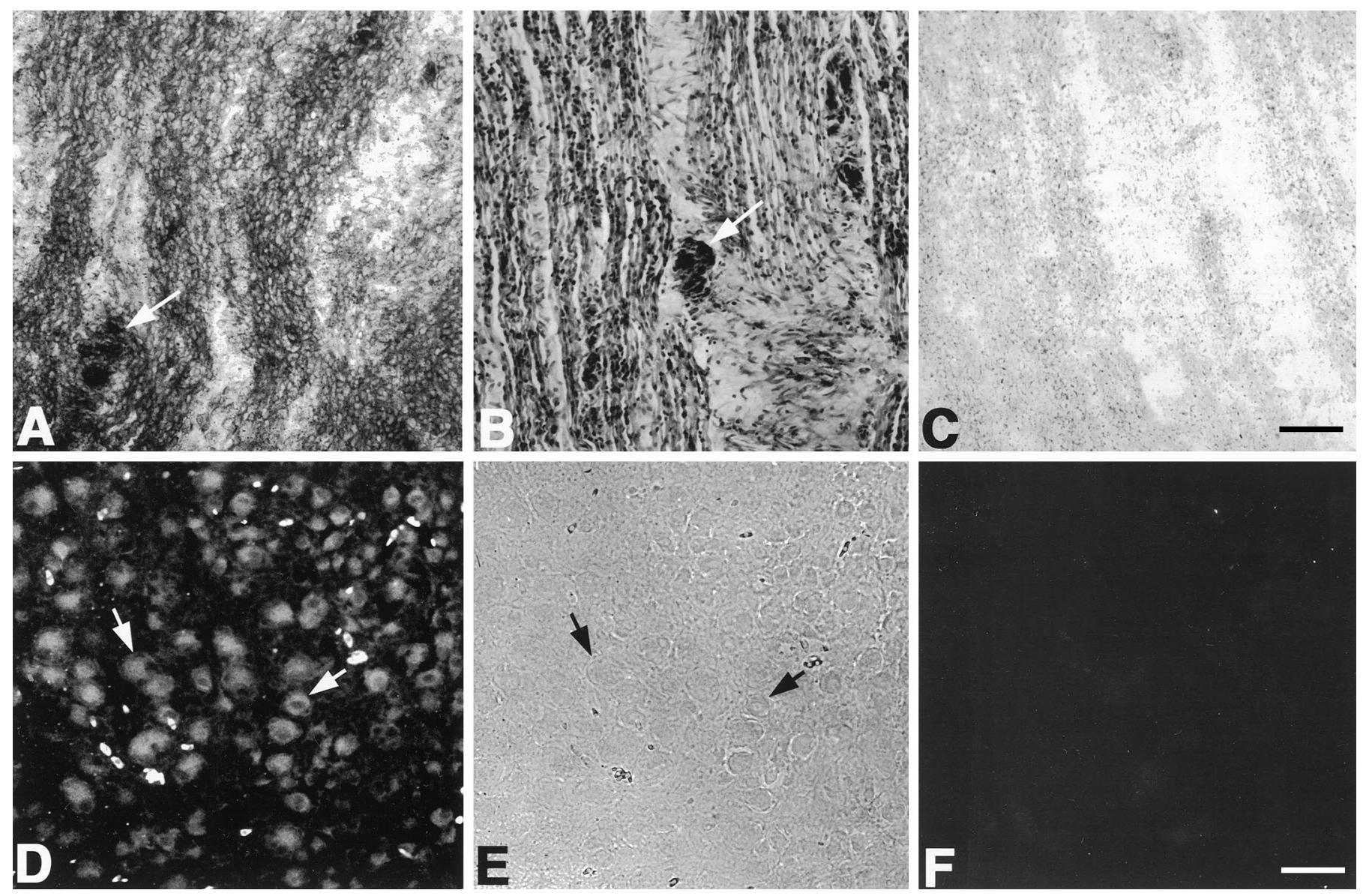

Figure 5. Localization of rapsyn mRNA transcript in chick muscle and ciliary ganglion. Tissue sections were hybridized with digoxigenin-labeled antisense or sense ChIN riboprobe, treated with anti-digoxigenin Fab conjugated to alkaline phosphatase, and visualized by bright-field (muscle) or fluorescence (ganglia) optics after reaction with a suitable substrate (see Materials and Methods). In muscle sections hybridized with the antisense ChIN riboprobe $(A)$, rapsyn mRNA is evident within extrafusal muscle fibers and spindles (arrow), whereas only background levels are detected after hybridization with the sense riboprobe $(C)$. An unlabeled muscle section stained for hematoxylin and eosin $(B)$ shows the muscle fiber and spindle morphology (arrow) more clearly. In CG sections hybridized with the antisense ChIN riboprobe, rapsyn mRNA is evident in neurons $(D)$, whereas no specific reaction product was detected after hybridization with the sense riboprobe $(F)$. Many of the labeled neurons in $D$ clearly overlap with neuron soma profiles revealed when the same section is viewed with bright-field differential interference contrast optics (e.g., arrows in $D, E)$. Scale bars, $50 \mu \mathrm{m}$.

A2 (Fig. 6A). Because internal regions that would recognize the rapsyn probe used for Southern hybridizations are conserved in all three clones (data not shown), failure to detect a correlate of CG4 after primary amplifications (Fig. 4) probably reflects very low abundance of its associated transcript in the ganglion. Whereas CG7 is likely to represent expression of Ch43K.1 transcript in both muscle and neuronal tissues, the relationship of CG11 and CG4 to muscle-derived cDNAs is less clear. Based on their size match with the primary muscle PCR products (compare Figs. $6 \mathrm{~A}$ and $3 A$ ) and their overlapping restriction profiles (data not shown; see Discussion), we speculate that both CG11 and CG4 represent Ch43K.1 cDNA variants having transcripts expressed in both neuronal and muscle tissues.

Comparing CG11 and CG4 cDNA sequences with Ch43K.1 exon borders (Fig. 2B) inferred from the mouse Rapsn gene (Gautam et al., 1994) provides some insight into the origins of the chick rapsyn cDNA variants. In particular, CG11 lacks the $5^{\prime}$ half of exon 2 starting at the putative AG/GT splice site and extending through the first LZ motif. CG4 lacks precisely all of exon 2, from $5^{\prime}$ to $3^{\prime}$ putative splice sites, including both LZ motifs. Because CG11 contains a part of the proposed exon 2, its origin is unclear. Its presence may be the result of transcription from a novel gene or indicate that exon 2 arises by splicing of multiple exons. Because CG4 lacks all of proposed exon 2 and is delimited by appropriate splice sites, however, it may represent a variant that arises by alternative splicing of the same gene that gives rise to Ch43K.1.

\section{DISCUSSION}

Rapsyn is a peripheral membrane protein believed to drive AChR clustering on mammalian muscle fibers. We initiated this study to determine whether genes encoding rapsyn-like molecules are also expressed in the nervous system, where they might be relevant to clustering neuronal AChRs. Based on clues from initial Northern blots and experiments using probes developed by cloning a chick muscle rapsyn cDNA (Ch43K.1), our results both support and extend this hypothesis.

Northern blots using a mouse muscle cDNA probe provided initial evidence for the expression of rapsyn-like transcripts of $\approx 6.0,4.0$, and $2.0 \mathrm{~kb}$ in both chick muscle and brain. Multiple rapsyn transcripts have also been detected by Northern analysis in Torpedo electric tissue (at $\approx 1.6,3.0,5.0,6.0 \mathrm{~kb}$ ) (Frail et al., 1987) and Xenopus embryos (at $\approx 2.0$ and $4.0 \mathrm{~kb}$ ) (Baldwin et al., 1988). Alternative splicing of a single gene is likely to be involved in 
A

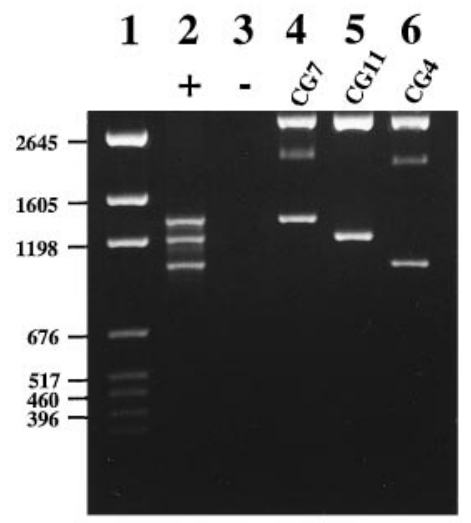

B

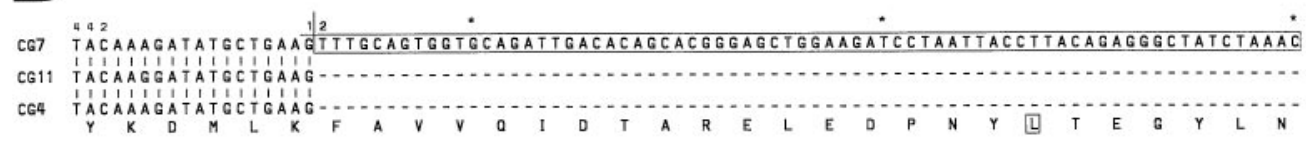

C67 CTGGCTCGCAGCAAT GAGAAACTCTGTGAATTCCAGAAAACAATATCTTACTGTAAGACATGCTTGAACATGCAGGGTACCACTGTGAGC CG11 $\ldots \ldots \ldots$. CG4

C67 C2 2 CCAGCTGAACGGCCAGGTGAGCCTCAGCATGGGCAATGCCTTCCTGGGCCTCAGCATTTTCCAGAAGGCTTTGGAGTGCTTTGAAAAA

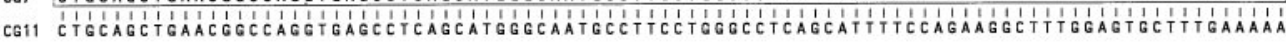

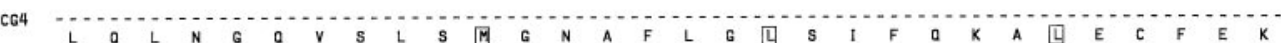
C67 GCTTTACGCTATGCACACAACAATGACGACAAGATGCTGGAGTGTCGAGTCTGCTGTAGCCTTGGGAACTTCTATGCCCAGATAAAGGAC CG11 GCT GTACGCTATGCACACAACA CG4 ${ }_{A}$ L L R Y A H N N D D K M L E C R V C C S L G CG7 TÅ 2 2 GAGAAACTTTG

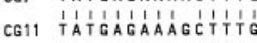
CG4 TATGAGAAAGC TTTE

Figure 6. Isolation, cloning, and characterization of rapsyn-like cDNAs derived from ciliary ganglia. $A$, Ganglionic cDNAs were reamplified using the nested primer pair (S2/A2), uncovering three products at 1350, 1250, and 1000 bp (lane 2) on ethidium-stained agarose gels. As in Figure 4, no products were detected when RT was omitted from the initial reverse transcription reaction (lane 3). Three of the cDNAs were subcloned (CG7, CG11, and CG4) and displayed insert sizes appropriate to the corresponding PCR products (lanes 4-6, respectively). B, Sequencing cDNA inserts from each of the ganglionic clones. Only nucleotides within and surrounding exon 2 (boxed region bordered by inverted Ts) are depicted, with dashes indicating nucleotides missing from CG11 or CG4 numbering above CG7 indicating the corresponding position in Ch43K.1 (see Fig. $2 B$ ). Amino acid residues encoded by CG7 and missing from CG11 or CG4 are shown in one letter code below CG4, with leucine, isoleucine, and methionine (leucine alternatives) (see Landschulz et al., 1988; Froehner, 1991) residues in boxes.

generating diverse rapsyn transcripts. For example, $43 \mathrm{k} .7$ and 43k.1, the two Torpedo rapsyn cDNAs derived from 5.0 and $1.6 \mathrm{~kb}$ transcripts, respectively, encode a full-length protein of 412 amino acids and a truncated protein lacking $23 \mathrm{C}$-terminal amino acids (Frail et al., 1987). The two Torpedo cDNAs begin to diverge at the exon 7-8 border, as identified from the mouse Rapsn gene, and the full-length protein would be predicted if intron 7 were spliced out, whereas failure to remove intron 7 would result in the termination of transcription and a truncated protein (Gautam et al., 1994). In mouse, the Rapsn gene (Gautam et al., 1994) apparently encodes a single $2.0 \mathrm{~kb}$ muscle transcript (Frail et al., 1988), and brain transcripts were not detected by Northern analysis (Frail et al., 1987). These findings suggest that a single type of mammalian rapsyn transcript forms a protein having a role restricted to clustering muscle AChRs. Our Northern blot and RT-PCR (see below) results detecting multiple rapsyn transcripts in chick muscle and neural tissue may reflect a less restrictive role for avian rapsyn proteins.

To develop chicken probes, a rapsyn cDNA (Ch43K.1) was constructed from partial clones isolated by screening an embryonic chick muscle library. Several aspects of the findings warrant note. First, Ch43K.1 represents a novel avian cDNA that was cloned from an authentic muscle cDNA library. Whereas Ch43K.1 is highly homologous to the cDNAs encoding Torpedo $43 \mathrm{k} .7$, Xenopus, and mouse rapsyn proteins, the earlier strategies used electrocytes (Torpedo), whole embryos (Xenopus), or transformed cell lines (mouse BC3H1 cells) as source tissue to generate mRNA. This raises the possibility that the resulting clones were not wholly representative of normal muscle. Second, the exon borders described for the mouse Rapsn gene (Gautam et al., 1994) are preserved in Ch43K.1. Although assignment of such borders is useful for explaining the origin of one truncated cDNA we subsequently detected and identified from chick CG, the exon border identification is tentative and awaits direct verification. Third, the predicted full-length chick rapsyn protein displays the same structural motifs thought to represent functional domains in other species (for review, see Froehner, 1991). In mouse, such domains are loosely correlated with individual exons of the associated Rapsn gene (Gautam et al., 1994).

Using PCR and Ch43K.1 primers, we detected multiple rapsynlike cDNAs of comparable size in templates derived from chick muscle or nervous tissue RNA sources. A number of trivial explanations for the findings can be rejected. First, detection of multiple cDNAs is not likely to represent a PCR artifact, because appropriate-size products were amplified when Ch43K.1 was used as template. Second, the products amplified from nervous system templates are unlikely to arise from genomic DNA, because all RNA preparations were treated with DNase before reverse transcription and products were never detected without cDNA synthesis. Third, the products detected in the nervous system are unlikely to represent amplification of contaminating muscle templates. For both ciliary and DRG, bits of adherent muscle tissue are removed by careful dissection, and yet products are amplified specifically from ciliary but not from DRG templates. Furthermore rapsyn-like products are amplified from chick brain but not from liver-derived templates, and yet both tissues are readily isolated with negligible risk of muscle contamination. Based on these considerations, the simplest explanation for our findings is that multiple transcripts for rapsyn-like proteins are expressed in both chick brain and CG. Coupling PCR with Southern blot hybridization using the ChIN probe was a key step in detecting neuronal rapsyn-like cDNAs and correlating their sizes with those derived from muscle. An obvious and intriguing exception to this general correlation is the $1600 \mathrm{bp}$ amplification product detected 
specifically in templates derived from ciliary ganglia and absent in those from muscle and brain. Given the relevance of clustered neuronal AChRs to synaptic transmission in the CG, we plan to characterize this cDNA further but do not yet know its relationship to Ch43K.1 or its functional significance.

In situ hybridization results indicate that Ch43K.1 mRNA is present in both chick muscle fibers and CG neurons. The muscle fiber localization is consistent with accepted ideas about rapsyn's role in clustering AChRs at skeletomotor synapses. More unusual is the presence of Ch43K.1 mRNA in muscle spindles, possibly within intrafusal muscle fibers. Such localization would suggest that rapsyn also clusters AChRs at fusimotor synapses. Ch43K.1 mRNA was also detected in large, round cell bodies typical of CG neurons. Some non-neuronal cells may also be labeled, but it was not possible to quantitate the relative degree of labeling in neuronal versus non-neuronal cells. On the basis of cell body size distinction, Ch43K.1 mRNA appears to be expressed in both ciliary and choroid neuron populations contained in the ganglion. Although we did not determine the relative numbers of labeled ciliary and choroid neurons, the expression pattern of rapsyn mRNA is consistent with a functional role, because both choroid and ciliary neurons display at least two AChR subtypes (Vernallis et al., 1993) that are clustered in or near the postsynaptic membrane (Jacob et al., 1984; Wilson Horch and Sargent, 1995).

Subcloning and sequencing revealed one ganglionic PCRderived cDNA as Ch43K.1 and two (at 1183 and 991 bp) as truncated Ch43K.1 variants displaying apparent deletions in a region corresponding to exon 2 of the mouse Rapsn gene. As with Ch43K.1, the two variants are probably not unique to the nervous system. Using nested primer pairs, secondary PCR products of indistinguishable size can be amplified from both muscle and CG templates, and digestion with EcoRI or NcoI revealed identical restriction profiles (A. Burns and J. Margiotta, unpublished observations). The relationship among the different Ch43K.1 cDNA isoforms at 1500, 1350, and $1150 \mathrm{bp}$ and the multiple rapsyn mRNA transcripts detected on Northern blots at $\approx 6.0,4.0$, and $2.0 \mathrm{~kb}$ are unknown. In Torpedo, the two rapsyn transcripts at 5.0 and $1.6 \mathrm{~kb}$ are correlated with cDNAs having coding regions that differ by $<100 \mathrm{bp}$; the disparity with transcript length is explained by differences in the length of $3^{\prime}$ untranslated regions (Frail et al., 1987). Because only one antisense primer (A1) anneals to a portion of the proximal 3 ' noncoding region, differences in more distal regions could also explain the length discrepancy between rapsyn transcripts and cDNAs. At present, the functional significance of rapsyn cDNAs we have identified is unknown. The absence of one or both LZ motifs in CG11 and CG4, respectively, may, however, provide an important clue. LZ1 and LZ2 are thought to form $\alpha$ helices, and both contain the seven consensus residues ("knobs and holes") associated with helix-helix packing of TPR3 and TPR4, respectively (Ponting and Phillips, 1996). Deletion of such structures in variant rapsyns could disrupt helix interactions implicated in permitting rapsyn homodimerization or heterodimerization with other membrane-associated proteins (Phillips et al., 1991b; Ponting and Phillips, 1996). Experimental support for this idea was provided by heterologous expression studies in which a mutant rapsyn protein lacking both LZ motifs and hydrophobic domains (residues 16-254) encoded by exons 2 through 4 failed to cluster AChRs but formed normal rapsyn aggregates (Phillips et al., 1991b). Because the two truncated rapsyn cDNAs feature more restricted partial and complete deletions of exon 2 , they provide a means of testing directly the in vivo relevance of one or both LZ motifs (and TPRs) in clustering AChRs.

Although additional experiments are required to document a functional role for Ch43K.1 and its variants, the availability of rapsyn-like cDNAs derived from nervous system transcripts are useful for exploring how AChRs become clustered at neuronal nicotinic synapses. Recent cloning and expression studies using spinal cord and hippocampal systems demonstrate that gephyrin (Kirsch et al., 1993) and PSD-95 (Kornau et al., 1996) co-localize with synaptic glycine and NMDA receptors, respectively, thereby suggesting that such molecules play a role analogous to rapsyn in clustering their associated receptors at synapses. Comparing the primary structure of rapsyns, gephyrin, and PSD-95, however, reveals a striking lack of homology. Given the analogous functional role suggested for such proteins, the absence of homology seems somewhat surprising, because nicotine, glycine, and NMDA receptors are all considered related families of ligand-gated ion channel proteins (for review, see Betz, 1990). Unraveling the mechanisms underlying the localization and aggregation of ion channels at synapses is fundamental to understanding nervous system development. Adding rapsyn to the list of divergent molecules involved in clustering neuronal receptors would suggest further that interaction between a particular receptor and its appropriate associated protein is a prerequisite for synaptogenesis.

\section{REFERENCES}

Apel ED, Merlie JP (1995) Assembly of the postsynaptic apparatus. Curr Opin Neurobiol 5:62-67.

Auffray C, Rougeon F (1980) Purification of mouse immunoglobulin heavy-chain messenger RNAs from total myeloma tumor RNA. Eur J Biochem 107:303-324.

Baldwin TJ, Theriot JA, Yoshihara CM, Burden SJ (1988) Regulation of transcript encoding the $43 \mathrm{~K}$ subsynaptic protein during development and after denervation. Development 104:557-564.

Betz H (1990) Ligand-gated ion channels in the brain: the amino acid receptor superfamily. Neuron 5:383-392.

Boyd RT, Jacob MH, Couturier S, Ballivet M, Berg DK (1988) Expression and regulation of neuronal acetylcholine receptor mRNA in chick ciliary ganglia. Neuron 1:495-502.

Boyd RT, Jacob MH, McEachern AE, Caron S, Berg DK (1991) Nicotinic acetylcholine receptor mRNA in dorsal root ganglion neurons. J Neurobiol 22:1-14.

Brennan C, Scotland PB, Froehner SC, Henderson LP (1992) Functional properties of acetylcholine receptors coexpressed with the $43 \mathrm{~K}$ protein in heterologous cell systems. Dev Biol 149:100-111.

Carr C, McCourt D, Cohen JB (1987) The 43-kilodalton protein of Torpedo nicotinic postsynaptic membranes: purification and determination of primary structure. Biochemistry 26:7090-7102.

Chomczynsky P, Sacchi H (1987) Single-step method of RNA isolation by acid guanididium thiocyanate-phenol-chloroform extraction. Anal Biochem 162:156-159.

Dennis MJ, Harris AJ, Kuffler SW (1971) Synaptic transmission and its duplication by focally applied acetylcholine in parasympathetic neurons in the heart of the frog. Proc R Soc Lond [Biol] 177:509-539.

Fertuck HC, Salpeter MM (1974) Localization of acetylcholine receptor by ${ }^{125}$ I-labeled alpha bungarotoxin binding at mouse motor endplates. Proc Natl Acad Sci USA 71:1376-1378.

Frail DE, Mudd J, Shah V, Carr C, Cohen JB, Merlie JP (1987) cDNAs for the postsynaptic $43 \mathrm{kDa}$ protein from Torpedo electric organ encode two proteins with different carboxyl termini. Proc Natl Acad Sci USA 84:6302-6306.

Frail DE, McLaughlin LL, Mudd J, Merlie JP (1988) Identification of the mouse muscle 43,000-dalton acetylcholine receptor-associated protein (RAPsyn) by cDNA cloning. J Biol Chem 263:15602-15607.

Froehner SC (1989) Expression of RNA transcripts for the postsynaptic $43 \mathrm{kDa}$ protein in innervated and denervated rat skeletal muscle. FEBS Lett 249:229-233.

Froehner SC (1991) The submembrane machinery for nicotinic acetylcholine receptor clustering. J Cell Biol 114:1-7. 
Froehner SC, Luetje CW, Scotland PB, Patrick J (1990) The postsynaptic $43 \mathrm{~K}$ protein clusters muscle nicotinic acetylcholine receptors in Xenopus oocytes. Neuron 5:403-410.

Gautam M, Mudd J, Copeland NG, Gilbert DJ, Jenkins NA, Merlie JP (1994) Characterization and mapping of the Rapsn gene encoding the 43 $\mathrm{kDa}$ acetylcholine receptor-associated protein. Genomics 24:366-369.

Gautam M, Noakes PG, Mudd J, Nichol M, Chu GC, Sanes JR, Merlie JP (1995) Failure of postsynaptic specialization to develop at neuromuscular junctions of rapsyn-deficient mice. Nature 377:232-236.

Hall ZW, Sanes JR (1993) Synaptic structure and development: the neuromuscular junction. Cell 72:99-123.

Halvorsen SW, Berg DK (1986) Identification of a nicotinic acetylcholine receptor on neurons using an $\alpha$-neurotoxin that blocks receptor function. J Neurosci 6:3405-3412.

Harris AJ, Kuffler SW, Dennis MJ (1971) Differential chemosensitivity of synaptic and extrasynaptic areas on the neuronal surface membrane in parasympathetic neurons of the frog, tested by microapplication of acetylcholine. Proc R Soc Lond [Biol] 177:541-553.

Heuser JE, Reese TS (1981) Structural changes after transmitter release at the frog neuromuscular junction. J Cell Biol 88:564-580.

Jacob MH, Berg DK, Lindstrom JM (1984) Shared antigenic determinant between the Electrophorus acetylcholine receptor and a synaptic component on chicken ciliary ganglion neurons. Proc Natl Acad Sci USA 81:3223-3227.

Jessell TM, Kandel ER (1993) Synaptic transmission: a bidirectional and self-modifiable form of cell-cell communication. Cell 72:1-30.

Kandel ER, Schwartz JH, Jessell TM (1991) Principles of neural science, 3rd ed. New York: Elsevier.

Kirsch J, Wolters I, Triller A, Betz H (1993) Gephyrin antisense oligonucleotides prevent glycine receptor clustering in spinal neurons. Nature 366:745-748.

Kornau HC, Schenker LT, Kennedy MB, Seeburg P (1996) Domain interaction between NMDA receptor subunits and the postsynaptic density protein PSD-95. Science 269:1737-1740.

Kozak M (1986) Point mutations define a sequence flanking the AUG initiator codon that modulates translation by eukaryotic ribosomes. Cell 44:283-292.

Landschulz WH, Johnson PF, McKnight SL (1988) The leucine zipper: a hypothetical structure common to a new class of DNA binding proteins. Science 240:1759-1764.

Margiotta JF, Berg DK (1982) Functional synapses are established between ciliary ganglion neurons in dissociated cell culture. Nature 296:152-154.
Margiotta JF, Burns AL (1995) Rapsyn-like transcripts are expressed in chick muscle and neuronal tissues. Soc Neurosci Abstr 21:801.

Margiotta JF, Howard M (1994) Eye extract factors promote the expression of acetylcholine sensitivity in chick dorsal root ganglion neurons. Dev Biol 163:188-201.

Paradies M, Steward O (1996) Development of differential localization of MAP2 and CaMKII mRNAs in neuropils of the rat hippocampal formation. Soc Neurosci Abstr 22:32.

Phillips WD, Kopta C, Blount P, Gardner PD, Steinbach JH, Merlie JP (1991a) ACh receptor-rich membrane domains organized fibroblasts by recombinant 43-kilodalton protein. Science 251:568-570.

Phillips WD, Maimone MM, Merlie JP (1991b) Mutagenesis of the 43 $\mathrm{kDa}$ postsynaptic protein defines domains involved in plasma membrane targeting and AChR clustering. J Cell Biol 115:1713-1723.

Ponting CP, Phillips C (1996) Rapsyn's knobs and holes: eight tetratrico peptide repeats. Biochem J Lett 314:1053-1056.

Sambrook J, Fritsch EF, Maniatis T (1989) Molecular cloning, a laboratory manual. New York: Cold Spring Harbor Laboratory.

Sargent PB (1993) The diversity of neuronal nicotinic acetylcholine receptors. Annu Rev Neurosci 16:403-443.

Scotland PB, Colledge M, Melnikova I, Dai Z, Froehner SC (1993) Clustering of the acetylcholine receptor by the $43 \mathrm{kDa}$ protein: involvement of the zinc finger domain. J Cell Biol 123:719-728.

Smith MA, Stollberg J, Berg DK, Lindstrom JM (1985) Characterization of a component in chick ciliary ganglia that cross-reacts with monoclonal antibodies to muscle and electric organ acetylcholine receptor. J Neurosci 5:2726-2731.

Snutch TP, Leonard JP, Gilbert MM, Lester HA, Davidson N (1990) Rat brain expresses a heterogeneous family of calcium channels. Proc Natl Acad Sci USA 87:3391-3395.

Thomas WS, O'Dowd DK, Smith MA (1993) Developmental expression and alternative splicing of chick agrin RNA. Dev Biol 158:523-535.

Vernallis AB, Conroy WG, Berg DK (1993) Neurons assemble AChRs with as many as 3 kinds of subunits while maintaining subunit segregation among subtypes. Neuron 10:451-464.

Wilson Horch HL, Sargent PB (1995) Perisynaptic surface distribution of multiple classes of nicotinic acetylcholine receptors on neurons in the chicken ciliary ganglion. J Neurosci 15:7778-7795.

Yu X-M, Hall ZW (1994) The role of the cytoplasmic domains of individual subunits of the acetylcholine receptor in $43 \mathrm{kDa}$ protein-induced clustering in COS cells. J Neurosci 14:785-795. 